\title{
【논문】
}

\section{Thinking of Being in the Perspective of Finitude*}

Park, Hyeon-Jeong

【Subject Class】 Ontology, Phenomenology, Existential Philosophy 【Keyword】 Infinity, Finitude, Consciousness, Being, Heidegger, Hegel, Derrida

【Abstract】 In Chapter 1: “Consciousness and Infinity," I will give a simple elucidation of the way in which traditional metaphysics deals with infinity and finiteness. The traditional concept of metaphysics as the self-consciousness of consciousness recognizes its own finiteness and supposes beyond all the finites "infinity," which means totality with eternity. With the supposition of "infinity" which only the absolute consciousness, reason, can recognize, human concrete existence, which is bound to its singularity, is denounced as the 'finite' once again. And therefore, we come to suffer the dichotomy which requires the endeavor of a reconciliation between the opposites in vain. In Chapter 2: "Hegel and the Last Solution of Traditional Metaphysics," I will examine the Hegelian speculative logic which is evaluated to have succeeded in the reconciliation of finiteness and infinity. He has rejected to admit the powerlessness of consciousness which is found in the spurious infinity of traditional metaphysics, and he removed the margin between us and

* 이 논문은 BK21 철학교육연구사업단의 지원을 받아 버팔로 대학(University of New York State at Buffalo)에 머무르는 동안 조가경 선생님의 지도 아래 작성되었다. 
ab-solute being. He made being move within a finite consciousness to the end, which gives totality to this movement. In this chapter, I will make clear that the reconciliation which traditional metaphysics has pursued has gained its fruit by the self-realization of consciousness as power to posit an order which can encompass being in a total system. In Chapter 3: "Heidegger and Co-belongingness of Thinking and Being," I will clarify what traditional metaphysics did not consider, that is, Being itself that is not regulated by consciousness and the genuine 'co-belongingness' between Being and Thinking. From this co-belongingness, our being becomes open-ended and we take the responsibility of the accomplishment of our own being. Here, it will be revealed that the concepts of finiteness and infinity should be abandoned, from the request of Being itself which is in union with Thinking, and therefore always in "finitude." In Chapter 4: "Derrida vs. Heidegger, on the Occurrence with Nothingness," I will advance to the elucidation of Being itself, how it enables the finitude of our understanding, and which task the co-belongingness of Being and Thinking demands us to accomplish. It is urgently necessary for us to think anew the 'Occurrence (Ereignis)' more precisely, the simultaneous 'annihilation (Vernichtung)' of Being itself. By clarifying the meaning of the self-withdrawal of Being, or annihilation, we would reappraise the unexhausted possibility of the late Heidegger's thought, which the so-called Post-modernists could have not drawn. I will focus here especially upon Derrida, who observes the 'Differance', which is structural infinity based on the 'otherness' or 'difference' of origin, against Hegel's 'identical' monistic thought. It is intended to mean the annihilation of Being, but actually means for Derrida the mere substitutions of presence by consciousness which is forgetful of Being itself. Along the way, I will show the reason for the forgetfulness of Being by consciousness and ask whether or not this is human beings' destiny. I will deal with the topic of language, not only because it was a main concern for Derrida and late Heidegger, but also because it is within language that the co-belongingness of Being and Thinking and thus "finitude" itself becomes most drastically problematic. In Chapters 3 
and 4, I aim to explicate, on the one hand, the difference between the thought of Hegel and that of early Heidegger, and on the other, the anti-metaphysical characteristic of the thought of late Heidegger, by elucidating why Heidegger could not help but naming 'Being itself.' Ultimately, in characterizing the relationship between Being and Thinking as a finitude which overcomes the dichotomy between infinity and finiteness, I want to understand human beings' genuine facticity and affirm it as it is. 


\section{I . Consciousness and Infinity}

Human beings' being is through and through finite. While alive, we always suffer from the differences which befall across space and time.1) In real life, I can never control the person next to me or even my own next being. As soon as one of two who have shared everyday life has his eyes opened to a new world, the experience must cause a crack in their relationship. One thinks that the other has changed, and the latter thinks that the former misunderstands him. Suddenly their words seem to refer to other things, and they are reminded of their difference. The interpretation is likely to miss the intention, and the sympathy between them is liable to be revealed as illusory. We suffer conflict again and again as time goes by, however hard we may try to solve this kind of problem. Every concrete person can not escape from her own perspective at each moment.

However, consciousness which is regarded as the most peculiar faculty of human beings makes an issue of this situation, in its own way. Human consciousness is not only consciousness of the objective conditions which are given to it, but also consciousness on the subject itself which recognizes the surrounding conditions, or self-consciousness which is aware of its own self. In its relationship with what is intended, consciousness always 'objectifies' its condition and even itself, within its own space for objectification ${ }^{2}$ ) and further, for

1) Here, I understand the predicate 'finite' not as mere temporal change of the 'isolated' me. For my change, I have to be in a relationship which makes me different at each moment. I will go into particulars in chapter 3 and 4 .

2) In chapter 4, I will elucidate that this space of objectification is the room for human 'freedom' which is however given from Being and which means thus our responsibility to exist finitely. 
reflection. We can never deny or disown this peculiar characteristic of consciousness, without which human beings are mere passive beings. In the reflection, what we encounter is the very fact that consciousness is unavoidably 'finite.' We can never penetrate or exhaust what is supposed to be reflected in our consciousness. Even the brightness of my existence which is reflected in self-consciousness is shaded wherever 'contents' matter.

Ironically enough, that is why throughout history, consciousness has sought to find certainty in things that appeared uncertain. To exceed its own limit, it pays attention to 'essences (hypokeimenon/substance)' among what escapes from our grasp because of its accidental quality. From these firm knots, consciousness weaves a web of order timeless or non-temporal beyond everything reflected. This order is outstretched over the world, in the unique space of consciousness which transforms the world. Only in this space of consciousness, the sensual disorder disappears and the ideal order appears. The wonder aroused by consciousness when it succeeds in organizing whatever that is, is one of the most important agents of philosophy.

This order is supposed above all to be 'eternal,' only because the order is 'ended' from the start, that is, already 'complete.' And this eternal order reaches every essence, thus everything that it assumes to be. Therefore, this order constructs 'total unity.' Here, we can find the joint of eternity or completeness and totality or unity, which represents homogeneity or isomorphism everywhere in space and time. We call totality and eternity by the name of "infinity."

The joint of all the concepts above, infinity as the everywhere -reaching, that is, 'perfect' realization of requirement of consciousness, as a matter of fact, includes the 'margin' by the omission of concrete finite progress of consciousness. When we investigate some 
'parts', and we find out one and the same pattern in those parts over and over again along the progress of this investigation, we assume that there is a whole which includes the parts and binds them up within an order. However, this is just an assumption which is required from our own limit of experience.

For example, when we imagine the mother who sheds tears because of a loss of her child, we can picture one drop of tears, and next, and another one again. We instantly discover a pattern there. The amount of tear drops grows quantitatively. So we can now suppose its expansion, even until it fills up an empty lake in our mind. As a matter of fact, if we try to continue the progress of figuring, along with the time which is needed for the actual tear shedding, we can never finish the progress, because it will take forever for the tear drops to fill the empty lake, thus to create a new lake. However, we can omit the annoying progress, and reach at sudden the supposed but unreachable end of the progress. The way we build up infinity is not that different from this fabrication. This is made possible only by omission that is grounded on the mere 'assumption' of the homogeneity of the world, which is originated and justified merely by the self-consciousness which is aware of its iteration of the homogeneous operation.

However, the reason that we can omit the progress is that, we believe, infinity itself is actual without our following it. We bind everything experienceable into an infinite whole that is not merely ideal but at the same time 'actual.' From this infinity back which has been posited by the demand of consciousness, our being is assumed to be thoroughly finite again. Our finite lives are not actual or true but imaginary and false.

Since it is consciousness that originates infinity, one peculiar 
consciousness, 'reason,' is arranged as the faculty which can get to infinity. Reason is the passage for infinity with which we have lost union. Reason is the origin of human beings' 'sanctity.' However, at the same time, consciousness is still caught in the human body which is so narrow and capricious for the recognition of infinity. Now, the characteristic of our existence which stands 'against' reason becomes the obstacle to re-idenfication with infinity. The history of philosophy is no more than the endeavor of consciousness to become the reason, which originates from the finite self-consciousness but ab-solutely divides itself from its own finite aspects. ${ }^{3}$ )

We posit infinity because we want to adopt a 'desirable' attitude toward our being: stability. However, we can ask: Did traditional metaphysics in fact succeed in overcoming finite existence by supposing that only reason can grasp infinity? Was it thereby able to overcome the finitude of our actual being? No. Rather, we are still suffering from the chasm between subject and object, universality and concreteness, thinking and being. To solve these problems which consciousness itself sets up, it has always tried to reconcile infinity and finiteness, which was an unattainable task from within, because it started with the false dichotomy which is forgetful of the co-belongingness of both.

3) Even in the existentialist stream which is valued to be extremely opposite to the traditional stream mentioned above among the philosophies before Heidegger, the understanding of infinity and finiteness is not that different from that of metaphysics. 


\section{П. Hegel and the last solution of traditional metaphysics}

1. Speculative logic as the reconciliation between being and thinking

In Hegel, the endeavors to reconcile finiteness and infinity at last achieved a result which could never be ignored since. Hegel combines logic with metaphysics. Logic is the method for discovering truth, adopted for finite human recognition or representation. On the other hand, metaphysics is the description of truth by reason which human beings share with the infinite, that is, God. However, Hegel joins these two divided sciences together into metaphysical logic or "speculative logic." Finite consciousness (Verstand) itself comes to describe the infinite, the absolute, in a proper systematization guided by reason (Vernunft).

Hegelian speculative logic constructs a 'system.' Here, human consciousness never presents a merely external assemblage of fragmentary contents. Here, a thesis, as knowledge, is directly followed by an antithesis which is a reflection of it. It is possible, because in this speculative logic, the 'one subject' as the middle, splits itself into opposed poles. And through synthesizing the 'objective' self and the self-reflection of it, consciousness comes back to a self which is not the same as the former one but belongs to a universal, higher order. Furthermore, this kind of sublation is not a single event; consciousness continues its 'spiral' progress of self-development until it can finally identify itself with absolute spirit, which encompasses as its knowledge all the finite moments of all the dimensions. In this speculative logic, by progressing, the middle, the consciousness gets the Concept, the 
most clear knowledge of itself, and at the same time, the form with full content.

In this progress, consciousness constructs a genuine 'whole (Ganze).' Because Hegelian speculative logic attains a whole in which the parts have their concreteness by the necessary relationship between one another. In his total whole, the contradiction or opposition between the moments is resolved into a necessary relation. And it is only when a whole gets its completeness as an organism and has a totality, that every part or moment comes alive and is endowed with any meaning. Every single moment becomes 'indispensible,' because without them consciousness could never have reached its end ${ }^{4}$ ) or become complete and thus infinite. Rather, the very movement of self-negating negation through the moments weaves the whole. Therefore, we can say that Hegelian speculative logic defines totality of consciousness without the abandonment of the finites.

\section{Beyond the spurious infinity}

What we find here is the reconciliation between finite consciousness and infinite reason, because consciousness sublates its finite self into an infinite reason which is total. However, as it is mentioned already, it is 'objectivity' of beings, including that of reflective

4) In this paper, "end" has three meanings: (a) the purpose, (b) what is to close the whole, (c) as, (a) and (b), what is given from the beginning. And I did not avoid using the same word for these different meanings, because I believe that these three meanings have the intimate relationship relating to infinity. Of course, the first meaning needs some comments, because it is used relating to the eternity which Hegel 'excluded' from infinity. However, even though it is not completely fixed in advance, infinity, the Concept is there from the beginning in the scene of movement. Therefore, we could say that Hegelian infinity still includes the 'eternity' in a converted meaning. 
consciousness, that requires consciousness to posit the infinite. The infinite consciousness is supposed to go beyond all the finite consciousness. However, how is it going with what 'is.' The epistemological totality would be different with the ontological totality. Therefore, we need to clarify not only the way each finite consciousness comes to unity, but also how we should understand the actual finiteness of being of beings in Hegelian logic.

People aim to explain the changes of the actual world but at the same time to ensure the possibility of infinity. Being should not prohibit the possibility of infinity. Therefore, the way traditional metaphysics solves this issue, is to deny and ignore finiteness of being which is actual, and to convert the concept of being to what corresponds to reason. When they mention substance or form, they are inclined to separate them from properties or materials. They say: what I am is a substance which is accompanied with these and those properties. However, properties are just contingent, thus will pass.5) What I am is a form which is bonded with some materials. The reason I am not perfect as a form is due to the materials. Here, they deny that what is contingent 'is.' For them, the genuine being is 'not' contingent. The contingency of being is 'not' truth. Being in its generation, change and degeneration is 'no more' than our mere presentation which originates from the limit of consciousness itself. Being itself is infinite, in the sense that it is 'not' finite any more.

Surely this dichotomy of truth and mere appearance or error is convenient. In the realm of 'truth,' we see the correspondence of thinking (reason) and the being (an absolute being) of infinity.

5) Metaphysics divides "essence (essentia)" from "existence (extentia)." (BP 328) 
Finite beings and finite consciousness look to be separated from each other. However, infinite being and infinite consciousness, reason are no more separated. Now, what matters is only the truth. Therefore, what matters for us is no more than the attainment of reason. By the conversion of the concept of being, they justify their pursuit.

However, when we understand being as ab-solute, as a matter of fact, the way of the pursuit remains unattainable at all. We cannot solve this problem with infinity which is the mere 'negation' of our finite consciousness and therefore absolute, because from the start, we have no way to cross the abyss between us and the ab-solute being. The romanticism represents the hope and despair of those who are trapped their own supposition of the ab-solute being.

Thus, Hegel regards the ab-solute infinity which is posited by the supposition that the true being is separated from our finite consciousness by its nature, as the 'spurious' infinity. Infinity as the mere 'opposite' of finite, contingent consciousness, is possible only by adding the margin of consciousness, which means the incapability of consciousness. The spurious infinity as the abstract negation of our finite experience can never be brought to an 'end' to be closed and therefore to be complete. As in the example of tearing mother mentioned above, the spurious infinity is entirely derived from the some accumulating some parts and the omission of most parts, that is, the skipping of a concrete progress and jumping into a conclusion. However, the adequacy of the omission can never be proved and posited scientifically. Infinity remains foreign to us as the other all the time, and frustrates our dream of reconciliation with it forever and ever.

In Hegel, the concept of eternity which is already complete is excluded 
from infinity. In this reason, I did not say that the Hegelian infinity is 'eternity.' In exchange for infinity, Hegel gives up the eternity which means what is complete from the beginning, thus what is non-temporal or timeless. Now, being moves with consciousness which is finite. His speculative logic walks each step of development of finiteness into infinity, on its own feet. In turning of the meaning of infinity into a totality which is filled up with movement without any margin in it, he reconciles finiteness of consciousness with infinity of 'being.'

\section{The relationship between being and consciousness}

As said before, Hegelian speculative logic is above all the development of consciousness, but it is also that of being which is not yet infinite from the start. Here, just as consciousness develops and changes, being itself is not free from mutation. Since Hegel combines consciousness and being to make possible the reconciliation of finiteness and infinity, Hegel posits 'being' which is not 'complete,' even at the "beginning" of his speculative logic. Being is not extra issue at all. Let us examine the way he treats this issue.

So far as it is a beginning, being should be simple and empty, not to include any other determination but itself (WL 79). Being as beginning cannot have anything outside of it, and cannot draw its progress from something else. Therefore, logic as the development of being should reach its end only from the beginning as a beginning through necessary progress. That is why the beginning is in the 'absolute' unity with its opposite which is not yet revealed, while it remains simple.

In speculative dialectics, being is in the absolute unity with its opposite, nothingness. Being contains a determination which is not 
external but necessary in itself, nothingness. Thinking being as a beginning means thinking nothing, which definitely differs from thinking something. Here, if we can say about the difference of the two cases, thinking nothing also has a meaning, and there exists nothingness in our intuition as a determination when we think nothing. Nothingness shares the same meaning or rather meaninglessness with being, and therefore nothing is identical with the pure being (WL 83). Being which has no determination but itself is nothingness.

Being and nothingness are in inseparable unity. Thus, the beginning of the speculative logic sets out with being and nothing or the identity of them, that is, the non-being which is being simultaneously and being which is non-being simultaneously. At this phase, what we see is already neither being nor nothing. The truth is rather that they are already transferred to each other. Being is solely in the transference to nothing, that is to say, being is solely 'becoming.'

His speculative logic begins with the being as a beginning, and on the beginning it completes a necessary system. It is not only the progress of consciousness, but also of the being, too. However, as it is clear enough, the undetermined simple is not different from the 'emptiness' of consciousness, which means that consciousness has no content yet. Here, simple being has no determination external to consciousness, against which consciousness stands. Consciousness which has its beginning in being, has already overcome the contradiction with its opposite, that is, the objects or being, and has no exterior. Therefore, the progress of development is the 'internalization' of its determination by consciousness. Being as the beginning or the emptiness of consciousness wins its complete Concept through its 'self' movement or the self negating negation. 


\section{Endedness of movement}

In Hegel, we find the union between finiteness and infinity, or the unity between being (Wirklichkeit) and Concept, through the necessary movement of the negativity. The Concept which encompasses all that is with a totality (infinity) without the margin of consciousness which actually means the insurmountable gap between us and infinity, is always in its dynamic movement through the finite moments. This Hegelian thought might have the right to be called the culmination of the thousands of years' tradition of thinking which has pursued the encounter with the infinite.6)

However, we could say that he attained this achievement by the completion of the long project of metaphysics, which could not be achieved until consciousness realized its full possibility, that is, the 'domination' of being by an absolute 'order' which is recognizable by consciousness. The total has the totality only by its 'principle (Prinzip)' as the final cause, which penetrates its moments in a necessary manner and moves them into development. Of course, this principle is not given in the beginning in complete fullness, therefore, we cannot say that everything is 'determined' in advance as in spurious infinity. Without actualization, it can never be complete. However, the Hegelian system is already 'determined' to be closed and complete when its principle achieves the full determination and it is moved by the force of the 'end' which is already there where a system begins, though in unfulfilledness.

The idea itself that end is already in beginning, is not foreign to the traditional philosophy, either. We can discover the end as the

6) And it also is the culmination of the modern philosophy which has brought the self consciousness of consciousness or the reflection into question. 
cause of movement, as the ground of the whole in Plato's concept of Idea and recollection of it (Er-innerung), or in Aristotle's concept of divine activity as the pure actuality (energeia) or final cause. It is quite the same with the concept of god's providence through world history in Christianity.7) In each of these cases, the end itself offers the firm ground for every contingency.

However, Hegel was peculiar in that he was never content with the confession of ignorance of the concrete progress of the self realization of the end. He goes further to describe the whole process by which this end gets its full content without any 'omission.' There remains nothing uncertain or obscure in his system, as long as it constitutes the system. In Hegelian speculative logic, consciousness has the clear self-consciousness. His logic is full of the confidence. It knows that it can force being to be subordinate to itself. This confidence is possible because his logic does not merely seek to 'find' out the order of the world, but to 'posit' the order itself, just as when we line up every organism in a genealogical table by projecting an invented order. In development, consciousness gathers everything within its earlier thrown net, thus its infinity is positive, full of the harvest.

In this way, instead of supposing infinity which is ab-solute vis-a-vis our consciousness, he elevates the determination of

7) Heidegger regards the end which is the Idea, the One or God, as 'present,' in spite of their explicit dynamic characteristic. It goes without saying that these ends are different from the other ordinary beings, because they cannot be sensed. However, each of them is a being (beingness/Seindheit) of beings, as the master of the other beings which has been authorized by our reflection. Because we do not ask its 'being' but treat it as a substance which has its immutable essence. How Being in Heidegger and this entity can be different, could be elucidated in this paper, with the concept of finitude. 
consciousness, the order of consciousness, to the highest height that we can reach. To ensure totality, he introduces the principle which is projected by consciousness itself, the absoluteness to which consciousness can stretch. Therefore, we daringly could say: ultimately, the Hegelian progress which reaches the infinite through all that is finite, is the self-raising of consciousness which reflects itself, to the absolute. The progress of being is actually that of the 'concept' of being which reaches the Concept, the absolute spirit which conceptualizes itself, at the end of development.

Therefore, it is natural that speculative logic cannot pay enough attention to singularities, because in the Hegelian system the finite which has its own singularity is the process of the end which is united. Rather, the Hegelian logic achieves the sovereignty of consciousness over being, necessarily only by eliminating the real characteristics of Being itself, and by vesting Being with the order of consciousness. In every manipulation, whenever we try to describe the process without omission, we cannot help but exclude many aspects that could not be subsumed within the order that originates from the end. For example, in Hegel every other relation except the contradiction is ignored. The contradiction between being and nothing is synthesized to becoming, and the contradiction between becoming and its essence is synthesized to concept. Every error which is introduced to the system is overcome and subsumed within a higher dimension. Therefore, the differences that cannot be sublated and synthesized are not included in the system. However, there are the numerous differences in the trivial aspects which cannot be organized to clean cut unity. In Hegelian logic, the others that actually are, lose their resistance. 


\section{Heidegger and Co-belongingness of Thinking and Being}

\section{Our open-ended being}

We can never ignore the teaching of Hegel. He did not conceive of being as already fulfilled without the need for the accomplishment or performance of consciousness. He let being move step by step through our finite consciousness. Even though we view Hegelian thought as still consciousness-centered because his ontology was not that of real being which is more than the empty beginning of speculation, the appropriate attention to the way in which this movement occurs would open a new vision, and show what our 'facticity' or 'givenness' is, against the violent presupposition of consciousness. Let me accentuate: the movement occurs on the 'border' between consciousness and being, or more precisely, in the comprehensive place which precedes and enables the dichotomy. Dialectic logic is the development of the 'one subject (absolute spirit)' as the middle term which splits itself into opposite poles, that is, the reflected and the reflection, and unites them into a higher dimension. Here, there is no consciousness which stands alone without what is reflected.

As is well known, there have been long debates on the paradox of reflection. When we try to suspend our usual reflection ${ }^{8)}$ and to reflect on the reflection itself, in this added second reflection, the self-consciousness of reflection itself escapes the ambit of consciousness,

8) [8] Here, the 'usual' reflection is thinking of something or more precisely, of the situation in which a consciousness belongs. It is not a thinking of thinking yet. I call it "reflection" because it is a (not transparent) 'mirroring' of what is. 
while it works. Consciousness splits itself into objectified consciousness and self-consciousness, and reflects the former by the latter. This progress seems to be an addition of reflecting consciousness to the usual consciousness. In fact, however, we can say that here consciousness divides itself into two parts, and mirrors one to another. And when we start meta-reflection, the former reflection which reflects the objectified-self is reflected on this new mirror. In the progress of this mirroring, a reflecting reflection itself becomes a new reflected image. We can continue reflecting until an image duplicates itself again and again into innumerableness.

However, this 'retreatment' is 'in vain' and cannot explicate the origin of consciousness, because the very regression of reflection begins with the self-splitting of consciousness and the separation of itself from the same by objectification and 'otherization' of the former. In this way, we can never grasp what reflection is.9) Separation of what is not in reality separated always fails. To elucidate the reflection, we have to pay attention to the reflection as a whole, without analysis. When we try to win an 'un-premised' beginning point, we always postpone thinking what we should think.

In the same manner, by separating consciousness from being as its object, we can never reach the full recognition of both. Now, it is demanded here for us to admit what is already given to our consciousness as the ground of consciousness and being at the same time. We are not entirely foreign to the reflected, being. We are already there where being of beings to which we are related shows itself. Speculative dialectics reveals the clarity (Helle) in which

9) We usually divide the subject from the object of reflection or consciousness. It has been a fundamental posit. However, we can never reach object in this way, rather we can only build the kingdom of subject, as the history of metaphysic (and Hegel) verifies. 
consciousness or reflection in unity with being has its own ground or beginning. Philosophy has to stay and think of this clearing which opens the way for it. We must ask about the possibility of this clearing more properly.

However, we must not forget that we have criticized the Hegelian logic for being consciousness-centered, and thus not knowing the 'other' origin. By Hegel, we have been taught that 'what is' reveals itself not from outside of consciousness, but through the breadth of it. It is not mere coincidence that the numerous thoughts could not find a way out of consciousness but returned to it again and again. The harder we endeavor to grasp the 'thing itself', the more keenly we come to realize that for us who already exist, it is impossible to suppose the exterior of consciousness. We have seen that even the furthest opposite of consciousness, the absolute, is determined by consciousness from the beginning in its characteristic of infinity. When Hegel admitted of our facticity that we can never go out of our consciousness which is already allowed to have knowledge of being, he was conscious that we are finite, even not in the traditional way. However, when he finally absolutized consciousness, he forgot to bring the 'other' origin of the disclosure which is not merely from our consciousness and thus annoying, into real question. He overlooked that what is only through our consciousness still should be questioned in itself.

However, we ourselves are not yet prepared to elucidate this occurrence positively, either. On that account, let us take a detour from consciousness with which we are already familiar. At least for our ordinary experience, being which offers itself within consciousness is contingent, and consciousness which recognizes contingent being is contingent, too. Consciousness and being are experienced as 
finite. Therefore, it is possible for us to refuse infinity with both feet and to open ourselves to restlessness. However, consciousness is characterized by its effort not to surrender to contingency but to conquer it. Consciousness always aims at certainty. Now we might be able to ask: why on earth does consciousness attempt a project which is possible only by elimination of what is real? Why does consciousness aim to close the end of being and to suppose an order within the whole? That is just because for us finite human beings, it is possible and required.

To accept our life as contingent is concomitant with ceaseless anxiety. Without the belief that our good deeds will bring good consequences to me or others, good deeds cannot be guaranteed and our life will look more perilous. The supposition of retributive justice in the whole universe actually affects our way of life. Human life is not only woven from the conditions given naturally, but also from values we create. What is evaluated as beautiful or shameful can even make one throw away his life, against the basic desire of organisms. The room for our evaluation is open to us already. What can this fact mean? That the future is 'open' to us as that which is to be chosen and accomplished by ourselves. We are destined to owe and take responsibility for our own 'being.' 10)

We are responsible for our own being, an obligation which can never be discharged even for a moment. When consciousness exposes this facticity, however, ironically enough it intends the

10) In the preceding explanation, "being" is of an infinite being or of a finite being: however, in each case, what is is objectified by consciousness, therefore the difference between being and beings is not clear here. However, being cannot be fully objectified in our consciousness to be analyzed, divided and sorted. What is crucial for the clarification of the difference, is to think its finitude, that is, to think its dynamic origin, which is the issue of this paper. 
opposite by supposing a being beyond all beings, that is, the 'beingness' which leads and masters us. It chooses to avoid its responsibility to choose. Consciousness often exceeds its authority so far as to conceal undeniable facticity by its hope or will.11)

However, because I want to elucidate the possibility of choice which is unconcealed by our ordinary way of choice, and which would prove our facticity that we are already there where we are not stranger for our objects, from now on, we can no longer stay under the sovereignty of consciousness. Therefore, we need some other faculty with which we can ask about being more appropriately, that is, in disclosure but without subordination to the self-insisting or overindulgence of consciousness. However, it cannot be denied that even though we acknowledge that we try to refuse consciousness-centered explication of being, at the same time we are the beings that can never be free from consciousness. Then how can we approach being? And on this way to being, how do things stand with infinity and finiteness?

\section{Ontological elucidation of the open-ended being}

A crucial hint for the answer was already alluded to above. We choose to be in the stability by our consciousness. If in the project of consciousness we bring our own being into question and decide an actual direction for our own being, we are able to see how being and consciousness are correlated. It is nonsense to suppose that I, as existent consciousness, am separated from my own bein g12) and determine my being from outside of it. Rather, consciousness

11) The relationship between consciousness and understanding, and the difference between human beings and all the other beings, will be explicated in detail in (4) authenticity and consciousness. 
itself takes part in my being. Then, what matters is the way in which consciousness 'is,' that is, the 'being of consciousness.' Now, therefore, if we would let a word replace "consciousness," it should manifest that we conscious beings are existent, thus that we are already in correlation with being, not in opposition to it. Instead of consciousness which has been supposed to be the opposite of being, Heidegger introduces the term 'thinking of being' 13) or 'understanding.' As far as she exists, a human being already understands her own being.

Here, 'understanding' is not a 'recognition' of an object which is called "being." A human being's understanding does not mean mere logical or theoretical figuring but the 'ability to be (Sein-können).'

12) Here, my being means the way I am myself.

13) The meaning of 'Thinking of Being (Seinsdenken)' should be explicated more. Actually Thinking of Being can be divided from understanding of being. The former means our bringing into question Being in itself,' while the latter means that which is 'taken by us (which is still 'transcendental').' Of course, as long as Thinking and Being co-belong to each other, these two questionings cannot be entirely separated, however, it is important to know the difference between these two questionings for the understanding of Heidegger's way of thinking. Here, I cannot but mention the difference between three phases of Heidegger's thinking, and the way I deal with them. His way is thinking of Being from start to finish, although Heidegger comes to beware that we should bring 'Being as such' 'from itself' into question since the middle phases after the so-called 'turn (Kehre).' And this is required by what is thought itself. In the progress of this paper, I will make clear that his thinking after the turn has a bright penetration, and I will rehabilitate it from post-modernist criticism. However, this paper repeats the terms of early Heidegger on purpose, because I myself believe, like early Heidegger, that we can never escape of our finitude, and that we cannot but think Being which is infinitude at best on the border of our limit. This paper is in some respects the development of the issue of early Heidegger with the later ontology of Heidegger, that is, it is the reconciliation of his early and late Thinking of Being. 
With this ability she has her own 'possibility to be.' And the possibility of being is not a mere unrealized or unrealizable possibility opposite to 'reality,' because this possibility is already fulfilled at each moment. If it were not, a human being would cease existing, as long as the possibility is the possibility to be. A human being becomes herself only by actualization of her anticipated possibility at each moment (SZ 193). Therefore, the possibility of a human being's being is not a mere negation of reality, rather it includes reality (SZ 51 2), and is more than reality.

However, this possibility cannot precede reality. Rather, the possibility comes into the openness only through and from reality. A possibility is not empty but concrete, being generated from what I am at each moment. For example, when you say 'now, it is possible for me to forgive them,' you have the possibility which comes only from the very way in which you are yourself, which is defined by your own reality now and here, and which is more than the logical possibility which is isolated from your real situation. That is why a human being's possibility is 'actual possibility (SZ 195).' A human being who understands its actual possibility is in the middle of accomplishment of its own being.

As long as understanding is like this, we can never be discharged from the understanding of our being. Usually people think of the merely occasional 'volitive' activity with the term "understanding." However, understanding is always already attuned. ${ }^{14)}$ 'Attunement (Stimmung)' here means the 'mood,' being in tune with some mood. In a mood, a human being is disclosed to its own being 'before' and far 'beyond' consciousness, in the range of disclosure. That

14) When we reject consciousness and demand understanding, the latter is already supposed to be less 'free' from being. 
mood opens and shows the trifling conditions all together (SZ 180) which consciousness never recognizes, can be shown, for example, in 'bad mood.' Sometimes I feel bad without any clear consciousness of why. Of course, I can consider carefully what makes me so depressed and trace the clues one after one, to find out the problematic situation with which my being faces. However, what initially reveals the situation as 'problematic' is definitely not consciousness but mood. And, a human being is unable to escape from the mood which reveals his being, under any circumstances. A human being can, should, and cannot but control mood with his consciousness. However, when I control moods, I do so not without mood, but with other opposite moods (SZ 178, 181).

This fact suggests that being is given to every each human being as a responsibility that can never be shifted and relieved, namely the facticity of the 'thrownness (Geworfenheit)' of human beings into being (SZ 178 180). I always care that I am and I have to be. After all, the correlation between our understanding and being is not arbitrary. For us, there is no choice but to take responsibility for bringing being into question. The Understanding of being is for us the burden that never can be removed while we exist.

Furthermore, the one who is thrown into being is me myself, not anybody else. This means that what matters is not neutral but always mine. Therefore, I am able to be thrown into being at each moment only through my own throwing (Entwurf). I myself accept my possibility and take responsible for the acceptance. The conscious decision can be made by others, but your being cannot be thrown by me. Therefore, that what I was yesterday cannot be the exact same with what I am right now, and that being is newly woven at each moment is true only by virtue of my each moment's 
understanding-my own ability to be of the time. I myself actualize my possibility and form being anew and anew, only by the accomplishment of my understanding at each moment. A human being is on the way to itself by its own understanding (O 40).

Like this, understanding and being are correlated inseparably. In a human being's understanding, the possibility of its being is actualized. To be more precise, (a) As far as a human being is, being is its responsibility. And (b) it takes part in its responsibility by its own accomplishment of its being. And, in this twofold way, being is again and again characterized by 'mineness (Jemeinigkeit)' and thus with 'finitude.' A human being's being is its own. We can say not only that being and understanding are correlated, but also that understanding and being are thoroughly identical by being 'finite.' It is not, however, in finiteness, because it has no absolute being and is no longer opposite to infinity. We do not take for granted any more that there is something infinite outside us, because my being is only through my accomplishment and if it can reconcile with the infinite, the reconciliation should be 'through' my own finite being, too. Therefore, we define the understanding of human being's being with another word, "finitude." Through the accomplishment of understanding. Being itself or Being as such is characterized by finitude.

\section{Being as such}

We can say that my being is characterized by finitude. However, how can we mention Being itself here? The being explicated above is mine, thus localized and 'partial' and 'instant' compared to the total and eternal being which traditional philosophy has pursued. How can Being itself be elucidated through my own being? People 
often believe that, as it is seen by the idea of Idea, there is a genuine being which possesses a fullness that other beings lack, and that thus a particular being can never represent genuine being of beings. When we believe that the each mode of love in reality is not the genuine love, we are already supposing an ideal entity which is the love of loves, the love itself. Here, necessarily, the concrete love which is in its own way of being is downplayed. It is not until we escape this myth of the 'itself,' that we can see my being as Being as such, as Being which opens itself into concrete beings at each moment.

When we regard my being as localized, we think it as a being (Seiende) which is discontinuous with others. Only beings can be discontinuous with others. However often we may confuse being (Sein) with beings (Seiende), being is different from a being. The singularity of being of a being does not mean that it is excluded from being of other beings. All beings are correlated to each other in their 'being (Sein),' and the relationship is not external at all. Each one that is, could not be isolated in its being. To think the being (Sein) of a being (Seiende), the relationships with numberless other artificial, natural or human beings should be considered. To be is actually to be a tie of relationships. I say "relationships," even though the relationship between the related beings is actually a 'singular' term. When I come to know a new inspiring friend, the truth changes my entire former relationship with my old friends. All the relationships are not just individual but indivisible. Similarly, my being is a 'singular' term, but not just one being among others.

However, this does not mean that there is a fact objectifiable as a connected net outside of me. When we think so, we are still thinking being as a being and thus separating being from our 
understanding. Contrastingly, I want to think the co-belongingness of being and thinking. The relationship is not objectifiable. Being is not only being of numerous beings, but also comes to be through disclosure. Heidegger defines the human being's being as being-there (Da-sein) where Being occurs. Although a human being is a being, we say that he is standing in the middle of a clearing as the common ground of its thinking and being. More precisely, now we can say that the very way that a human being is, is to be as the clearing. There is not before and after or in and out between human understanding and its being.

That is why in the clearing where numerous beings come into being and go out of it, these beings always appear 'as' somethin g. ${ }^{15)}$ Furthermore, a human being understands its own being which is related to other beings in its disclosure. The existence of Dasein is to determine how the world would be from the un-determination before my own accomplishment. All beings get their own peculiar places and uses at each moment in my own understanding. Through my being which is mine, the relationship between all beings attains its unique singularity at each moment. The dinner which is shared between those who have separation without any promise ahead, get its singularity only through their being. 16) As far as a Dasein exists as an understanding, it is always the clearing for the appearance of all beings in their relationship at each moment, that is, in a specific singular way. Now, we can say not only that the being that reveals

15) Then, the disclosure through our understanding is 'relative'? No. Because it is from Being itself as the origin of my understanding. I will come back to this issue indirectily in the last section.

16) However, how should it be understood that each human being has a different disclosure? This issue will be treated at length in the next chapter, where 'nothingness' of Being is elucidated against the so-called post-modern criticisms. 
itself in the disclosure which is characterized by mineness exists in finitude, but also Being as such, which is the same thing, gives itself in finitude.

However, why do we need the concept "Being as such," if it joints hands with my being? Because we need to ask about the 'origin' of my being. This question of origin cannot be an additional, extra one at all, since my being originates from the origin again and again at each and every moment. Let me clarify the horizon of the question a little bit more. Dasein exists through opening up its own possibility at each moment. As said already, my possibility is defined by its own singularity. Therefore, my possibility has its entireness (Ganzheit), and thus its limitation or end (Ende) (KM 210) which is already complete and open at the same time. Of course, this limitation is not the concept which presupposes total or eternal understanding. It is related to the each moment's singularity. With the limit, I exist 'as' me, and to exist as me requires not to exist someone else. Therefore, to be a Dasein means being the ground of a nothingness (Nichtigkeit) at the same time (SZ 377 378). Taking the responsibility for its being means to ground a nothingness, which is the impossibility of the possibility of being. Here it is important that a disclosure, outside which there cannot be any other ground for its being, already joints hands with a nothingness.

However, Heidegger says that nothingness cannot be regarded merely as the 'negation' of present understanding (EM 5). For example, an apple which is seen by me is green, it is not red, yellow or violet. However, this 'not' is not what my being at this moment grounds, because this 'not' is not actual, but just theoretical. Dasein does not exist as a being just for a fleeting moment, but 
moves and draws again and again its new possibility which exceeds its former limitation in activity. If I accomplish these possibilities anew, the issue here is the annulling of a ground, the 'de-ground' (Ab-grund) from where my disclosing understanding, and being of all beings which appear into this disclosure, draw their own finite possibilities anew.

If we can identify this nothingness with the negation of my present understanding, it will mean that $\mathrm{I}$ am the origin of myself and the other beings. However, from where a dynamic movement in which my every being-there comes to existence anew originates? The occurrence (Geschehen/ Ereignis) itself is not from me, even though it happens through me. So Heidegger wants to think again and afresh of the negative movement, or self-annihilation of Being itself, in the perspective of the origin of all beings. The endeavor to elucidate nothingness 'of' Being characterizes the Heideggerian thought after middle phase ${ }^{17}$ ).

What Hegelian thought lacks is not the movement of finite consciousness but the genuine origin of the 'negativity,' which is in him merely ascribed to absolute spirit as the principle dividing and uniting itself. He should have brought the origin into question more closely. Because we no longer want any metaphysical devices, we ask 'how' Being itself 'is' as the generation and degeneration of multi-multiple singularity. Therefore, the concept of 'Being as such' is required to make clear what finitude is. It is introduced to ask what consciousness which crystallizes being into 'presence' forgets. The question of what is not present, nothingness or the negative movement of Being itself, is the most profound of all questions.

17) I follow the division of Heidegger's phases by Jae Chul Youm in Heideggers Verwandlung des Denkens (Königshausen\&Neumann, Würzburg, 1995). 
However, before we question nothingness, let us clear first the relationship between consciousness and being. To do this, I will investigate so-called 'authenticity.'

\section{Authenticity and consciousness}

There are two reasons that I introduce authenticity. First, it is to clarify the status of consciousness which is definitely a way of Dasein's being and yet a denier of being at the same time. Although we began the argument with the characterization of consciousness, we let understanding replace it, without enough clarification of the identity or difference between consciousness and understanding. Considering the share which consciousness has had for thousands of years in history of philosophy and in our actual being, it is unsatisfactory to omit a weighty discussion of consciousness. And here the 'authentic' being of Dasein will be inquired, not only because it is the most intrinsic mode of 'understanding' which is the accomplishment of the finitude of being, but also because it includes the most far-reaching human way of being, 'consciousness,' at the same time. While examining authenticity, we would recognize the twofold relationship of consciousness with being which enables the twofold status of consciousness in Heideggerian thought. However, this twofoldness is elucidated from the occurrence of Being itself, which holds nothingness in it, in the middle phase of Heideggerian thought. Therefore, secondly, this section will also be a stepping stone to the next chapter which asks about the occurrence and nothingness of Being, as well.

Authentic being is not a moral ought, but an extreme possibility of Dasein, an intrinsic way of being of Dasein. The Dasein who is in its authentic being ceaselessly repeats its own de-termination 
(Entshlossenheit). De-termination means taking the responsibility of its being from its end. ${ }^{18)}$ The Dasein who is in its authentic being, discloses a clearing and foreruns to the end of the disclosure, to its death as the most 'extreme' possibility. ${ }^{19)}$ It throws itself from its death back into the concrete clearing and opens its defined possibility as its actual possibility. Further, because all the understanding is already attuned, it commits itself to an inherited possibility which is most peculiar to it at each moment. By doing so, it exists 'momentarily (augenblicklich).' In other words, to be authentic means to adopt the finitude of Being itself in an out-and-out way. Here, we find that the authentic being is not that different from being which was mentioned above as human beings' being, except in the extreme limit, although the new concepts of 'death' or 'determination' have been used here. However, Heidegger makes authenticity somewhat special by saying that being of every Tom, Dick and Harry is in an inauthentic way and in the 'forgetfulness (Vergessenheit)' of its being.

Because of this position, the interpretation which posits the concept of authenticity against his original anti-metaphysical project is pervasive. People confuse authentic being with the disenchantment of the sages who made an instant contact with the revelation of

18) Here, "end" does not mean purpose. A Daseins's end is its death, but not a biological death. When we think of the entireness (Ganzheit) of a Dasein with its biological birth and death, we are still regarding it as a being (Seiende) among others, not from its unique way of being as the clearing of Being. Here, "end" means the open limit of each moment's being. This concept needs a long page to be elucidated. I have to postpone dealing with it fully.

19) As I said above, the 'possibility' of being is not a mere negation of reality. Therefore, the death as the most 'extreme' possibility is not a mere empty but a farthest possibility. Rather, it is the realest possibility as the impossibility of possibility at each moment. 
god or the eternal and total truth. Here they suppose that authentic being is the ideal or the purpose outside of us which we should pursue. Or people might say that it is true that authenticity is already inside us but it cannot last in our ordinary being. Since animal nature which corrupts us, governs our ordinary being, the reason which is the core of humanity can be displayed only occasionally. Here, they treat human beings as the 'rational' animals. However, only those who seek metaphysical infinity require these kinds of comprehensions about authenticity of human being. Therefore, we do not want to identify the authenticity with the rationality which is potential but not actual possibility.

Nonetheless, these interpretations have some elements of truth, because in Heidegger authenticity is definitely related to consciousness. The early Heidegger says that human beings are different from other beings, because they are as the very place of the disclosure of Being, where the other non-human beings appear. However, we could say that in one sense all beings have the understanding of their own being, because they accomplish their own possibilities, too. I will call this kind of understanding "low-dimensional." They do not know what they are. They cannot reflect or make choices with so-called 'free will.' They lack the understanding in "high-dimensional" sense which makes possible the 'explicit' bringing of being into question. We have no ability to separate this faculty from consciousness. Thus, it is not a mere coincidence that the early Heidegger who speaks of authenticity, regards human beings as special and values (even in the middle phase) willing (or tries to give it up).

Actually, in his Being and Time, authenticity is continuous with the bringing of being into explicit question. Even though it is 
revealed that understanding and being are inseparably correlated in all beings, understanding is here the mere 'ontic' term which has not yet undergone the reflection. However, philosophers cannot be content with the ontic understanding; they always pursue the 'ontological' understanding of being. And this ontological understanding does not merely treat of beings, but brings being of beings into explicit question. In Ontology (1923), much more explicitly, Dasein is not only the one who accomplishes its possibility of being, but also the one who is 'conscious' of itself as such a being (O 18). The Dasein that is always on the way to itself, becomes itself by taking its responsibility to bring being into question as 'deserving' of questioning. The philosophy which brings being into explicit question, or hermeneutics, is the radicalization of the possibility of the being of Dasein. Since consciousness cannot be external to human beings, philosophy cannot be peripheral or subordinate.

However, we should note that the core of Heideggerian thought is not the division between these two dimensions but the unique cohesion of them. As a matter of fact, traditional metaphysics itself was the struggle for the reconciliation of these two dimensions. However, it emphasizes the dimension of consciousness, which causes the failure. Heidegger goes another way. In Heidegger, consciousness is not a mere epistemological agency. When consciousness is conscious of itself, the experience does not end in mere knowledge, but it instantly changes the way of being, too, because consciousness itself is a way of being. The Dasein that brings its own being into explicit question, that knows the finitude of its being and that asks what its best is here and now, comes to accomplish an entirely different being from the other's. Here, consciousness is definitely 'free' from what is present right now and it has the power of 
imagination. However, at the same time, the freedom is not unlimited, it should endure the given, the limitation, to be defined in the continuum of its own being. Authentic being demands that consciousness should take the burden of finitude willingly, and when a Dasein exists authentically, it is not a mere demand but a willing itself. Therefore, in Heidegger, consciousness is assimilated into accomplishment.

Regarding the seeming autonomy of consciousness, and for the resolution of left suspicion, let me ask: from where does consciousness emerge? And what is it for? It is noticeable that every Dasein gets consciousness only from and through the accomplishment of its own being. We think that we know a lot of things without 'experience.' However, at least every vitalization and expansion of knowledge has its ground in experience. A baby who has just been born and has never experienced any suffering with its own body cannot yet make any analogical inference. The plentiful knowledge which is current and valid in the world, emerged from what some person once experienced. For example, suppose that a person has heard that 'a $30 \mathrm{~cm}$ - or 10 foot-long stick is needed here.' The fact that he is conscious of the knowledge of length means that he already has experienced not a few cases in which the length of something matters.

Consciousness has its origin in each person's being. Therefore, no consciousness is as objective and evenhanded as is supposed. Rather, it is destined to be finite just because of the finitude of its being which is accomplished at each moment through an open-ended entireness. A person who is used to measuring in miles consciously understands the speed limit of 55 mile per hour. But when she crosses the border between countries and comes across the traffic 
signal which refers to the speed limit of $60 \mathrm{~km}$ per hour, it is not possible for her to be conscious that she is driving too fast, and that she is supposed to slow down the car, until she actually converts the $60 \mathrm{~km}$ into 37 miles which she knows the meaning of by her own being. And furthermore, if she is a beginner driver, a stranger in that area, or a person who has experienced a car accident lately, she will be conscious of the speed rather quickly. On the contrary, if she is a speed maniac, a person in a hurry or a skilled driver, she will be conscious of the same speed rather slowly. Here, since consciousness itself is intermingled with my being, and since therefore it is more than a 'mere' knowledge, evaluation or imagination, it can explicate the states of my being, and in the opposite direction, can be a rudder for my being.

As said before, authenticity is the extreme way of being of Dasein in which consciousness is intermingled with being in one piece. Consciousness is a way of being, and definitely has its indispensible role: to make our being reach farther. However, we cannot deny that often enough consciousness and being seem to be directed in opposite ways from each other. It is implied that consciousness has led the history of philosophy into the forgetfulness of Being. Consciousness is, like sight, far-reaching and thus, at the same time, attracted by what glitters. It likes to survey in the light, and dreams of a world which is filled up with unshadowing light. It never looks back on our own seeing which opens the clearing. It never sees those glittering beings as they are. It forgets to question the lightening or darkening itself. Consciousness has its character which is its strength and also weakness.

Because of this disposition of consciousness, also in Heidegger, authentic being which, as the intimate adhesion with consciousness, 
requires consciousness to remember Being, is rare. However, I do not mean to disparage our actual way of being with the mention of authenticity. Authenticity and inauthenticity of being are not contradictory or dichotomous. Rather, they are equiprimordial (gleichursprünglich), since both of them are grounded on the same fact that we have responsibility for our own being and that consciousness belongs to our peculiar way of being. People often think that truth and error have other origins because they are different in essence. However, the very same fact enables the authentic being and inauthentic being at the same time. Therefore, that our way of being itself includes consciousness which can conceal its finitude, that our way of being can deceive itself with false promises, is itself the facticity of human 'being,' which is given by 'Being.'

Human beings are those who get tired of everything so easily, and at the same time dream of the total peace of heaven; who cannot fasten their own mind even for a short while, and nonetheless crystallize the truth into eternity. If Being itself which we bring here into question is the origin of our being, it should be elucidated how Being enables us to be in the special way, that is, with consciousness which can fly away from our being. This twofold movement of Being itself is also related to nothingness, in middle and later Heidegger. Therefore, the understanding of nothingness is required once again for us who posit infinity against the actual finitude of our being. 


\section{Derrida vs. Heidegger, on the Occurrence with Nothingness ${ }^{20)}$}

\section{Differance as Structural Infinity}

The French, so-called deconstructive philosophy which inherits the thought of Hegel and Heidegger in a critical manner, thinks disclosure (which grounds consciousness) with a perceptive sensitivity. What matters for Hegel is not the categorization of the determinations that are appropriated in the realm of consciousness, but the elucidation of the negative movement as the principle of the grounding and the sublation of them. Only in this movement, the finite determinations have their peculiar places, becoming the inevitable moments. Derrida likewise pays attention to the vertical movement which arouses consciousness from its origin. Therefore, Derrida refuses to stay inside consciousness, but rather wants to get to the 'transcendental' sphere, that is, he thinks on the border between appearances and their origin which is not consciousness any more (MP 13), and is the place of disclosure.

Derrida penetrates the Hegelian movement that it builds up 'totality' which is presupposed by consciousness. In Hegel, infinity gives itself into the finites and negates them at the same time. However, since this negating movement has its end and is led by its telos, which is actually given by consciousness and organizes the finite determinations in order, it comes to be characterized by 'identity,' and once again falls into the hands of the philosophy of

20) For the elucidation of nothingness, I work on Derrida here, and this tactic has the obvious advantage of providing a consideration post-Heidegger discussion on this issue: finitude or infinity. 
identity or oneness. Therefore, Derrida rejects the Hegelian 'teleology' and denounces the 'monistic' philosophy which has one telos and thus is to be closed. In Hegel, infinity is 'positive' by the telos. However, in Derrida, the movement of infinity does not progress to higher dimensions with being led by the telos, but it is always 'open.' Therefore, since the vertical movement has no end, its determinations can never be completed.

In traditional metaphysics the end itself turns out to be the 'origin' which was there from the beginning, but Derrida refuses the origin as end: his origin also is what can never be 'complete.' The 'thing itself' is the invention of the consciousness which aims at the completeness of determination, and projects its end back to its origin. Even though in Derrida the finites that appear in their definite determinations are engendered by the origin which offers itself as the finites by its vertical movement, this vertical movement itself is 'difference.' It is different not only because it is the origin which engenders the differences which consciousness grasps, but also because movement itself is entirely 'different' from the work of movement. The former is 'other' than the latter which is the result of it, that is, beings. The former is the 'Other' to the beings which are present and thus always confined in a determination. The Other is the 'trace' in the sense that it cannot be characterized by presence, nor mere absence, as beings can. More precisely, it is "archi-trace" which always offers its surface, the appearing trace, ${ }^{21)}$ by erasing

21) Beings are also 'traces' because they can never be fully 'present' on the criteria of traditional metaphysics. Rules or regulations for the present entities, and their truth to which consciousness pays attention, cannot be the origin which actually engenders the appearance of beings. Rather, they are later (nachträglich, après coup) and supplementary constructions after a movement. Presence itself is not a fact, but a constitution. Here, Derrida regards the appearance to be closely related 
itself and recording itself into the trace at the same time.

Here, archi-trace offers itself as what cannot be exhausted (apprioriation) by the finite traces. It remains all the time as the absolute Other which cannot be present fully through our consciousness. Only what is present can be exhausted. Rather, the original difference is what cannot be referred by the appearing beings and its 'meaning' cannot be fixed because it is always "deferred" in any determination of meanings of the appearing beings. The Other is the self-deferring difference, "Differance (Différance)." It differs itself infinitely against the finite traces that are grasped by consciousness. This Differance is the alterity which can be drawn infinitely. All present law is the shadow of the good to come (if only in hope).

However, archi-trace is not something merely indefinite or undetermined. On the contrary, it has a clearly defined "structural (IDJ 139)" feature that implies the inexhaustibility. Therefore, archi-trace is as 'structural infinity.' Here, we should note that he already admits the realm of 'disclosure' which precedes the subject-object dichotomy, because our consciousness itself, which includes all beings, already belongs to the 'structure.' However, it is of decisive importance for Derrida that the origin of beings is still the 'Other.' Derrida confronts the 'indecidability' or open-endedness of being, which is contrary to our hope. What appears comes only from the other 'origin,' or the 'other' origin (NII, 95).

Here, he employs a suitable analogy of the language. Between the appearing beings and the words or marks, a strong analogy comes into existence. Frequently, we treat words or marks as signifiers which refer to the signified. However, there is no monosemic

to the 'presence' which necessarily causes consciousness to posit beingness and absolute entities. 
signified or concept outside the signifier. That we can never find a clear-cut definition proves that the monosemic signified is merely our invention. Even though it seems that we can pair a signifier and a signified in ordinary usage of language, when we read out a meaning, we are not following a pre-established meaning. Rather, we are creating a meaning by the 'performance' of language.

However, as it has already been seen, Derrida admits the field of disclosure in which origin of beings has a unique relationship with beings and our consciousness. It is the same with language, therefore, language comes to words through our possibility to say something or to perform a language practice. The performative act of language is always preceded by the "proto-act of assertion" anticipating the happening of language. When we start to say a word, we already should be in a disclosure in which what is to be said is revealed and thus enables the immediate performance of the language act. I can feel that I am ready to say. To be ready for the practice of language, we must assert what says itself before language. Derrida knows that I am ready to say something by the proto-language, quasi act, which is called "archi-writing (écriture)" or archi-text that is the origin of our language.

However, for him this disclosure that enables the relationship between archi-writing and me includes a deep abyss (epacement) in it. When he uses the analogy of language, this abyss announces itself more clearly. Language is not a device which is invented by human beings, but the performative act which is written by the primitive writing or text. This being the case, can we fairly expect the archi-text to 'correspond' to our interpretation through language? Derrida takes the opposite standpoint. Archi-writing is the origin of our language, however, it does not ensure that our language 
exhausts the origin. In reality, we always go through the difficulties for 'conversation' with language.

Suppose that we are trying to discover the meaning of words someone speaks. Initially, I detect that the person, whom I cannot trust, unexpectedly approves of my suggestion. In a moment, I become doubtful whether my interpretation is not a misunderstanding, or whether there is not another meaning that I could not penetrate. With what can I rid my mind of doubt, then? If two people listen to the spoken words, and the understandings of them do not coincide, how can we agree on which is the true interpretation? Should we appeal to the intention of speaker? Can we say that even the speaker is fully and without distortion conscious of her own intention at the moment the words were spoken? And even if she had a clear consciousness of what she did, can language echo her intention without any disturbance?

All of these hermeneutic questions are grounded on the same presupposition that the words which are spoken at some moment, under proper circumstances, save archi-trace fully and can reveal it without impairment. However, as it has already been pointed out, in Derrida archi-text is self-deferring Other of the marks of language, and thus without saying of our interpretation. What we readers see as given is just a specific mark which is a trace or a ghost of archi-text. The meaning of language should be determined by the supplementary act which determines a meaning of a word by the comparison of words in context, and here, such a determined meaning is nothing more than a temporary or provisional one. We can never reach stable determination and eternal rest. However often we may forget that the monosemic meaning at which our consciousness aims is a mere invention, archi-text itself is writing which resists exhausting reading. 


\section{Difference and Identity}

For Derrida the hermeneutical issues matter because of his anti-metaphysical and pessimistic ontology. To clarify the way in which he deals with these issues, it will be useful to compare his answers with those of Gadamer. In the debate with Gadamer, Derrida showed doubt and distrust of the possibility of conversation which is mediated by language. Since for Derrida the main concern was the anti-metaphysical thought, the so-called deconstruction of metaphysics, he wanted to refuse all kinds of unity and oneness, even taking a pessimistic view of the universal ground for hermeneutical experience.

In Gadamer, the text is not merely 'other' to our interpreters. The horizon of a text and that of an interpreter are subject to fusion (Horizontverschmelzung) and can create a new text. Of course, there is something to be said 'in' the text. However, what announces itself (Urkunde) in a text is not fixed before an actual interpretation, but comes to be determined only through it. When we understand it, we do it differently every time (WM 302) because the text itself is unclosed and uncompleted. It thus has a historical characteristic, and its meaning changes with time.

The fact that an interpreter takes part in determination of meaning of a text, arouses a problem. In this relationship, the interpreter who, for Gadamer, cannot be unconcerned with her concrete being, but, on the contrary, must have the 'openness (WM 273)' to be 'willing' to take part in a conversation (Gespräch), by offering itself as the place of play of a text. The act of participation and the openness happen simultaneously; therefore, the one who participates is open, and the one who is open already participates. Here, to be 'willing' to take part in a conversation cannot be reduced to the 
mere arbitrary intention of a subjective consciousness, although it is not unrelated to it. If it is so, then, we could say with right that every interpretation has a perspective, and is characterized by the willing of someone who offers the perspective, which prevents the possibility of 'genuine openness' to a conversation.

This was actually the point of Derridian criticism.22) He saw an insurmountable difference between openness and willing or text and interpreter. The willing which belongs to the interpreter can never be open fully, can never across the abyss toward the text. Even the intermediates, words, are mere traces which can neither exhaust archi-trace nor be a firm ground of meaning, so they are incapable of bridging them. Now we can see that in Derrida, interpretations are understood as those which have the will to 'exhaust' their origin with their finite determination, which is impossible because of the 'otherness' or 'difference' between words and archi-text.

However, we cannot say that there is only 'otherness' between archi-text and interpretation. We should pay attention to that language is the ground of the 'application' of a text, that is, is the ground of a 'perspective' and that of 'universality' at the same time. Even though we always fail to reach others fully, we at the same time never entirely miss them. The point of view that language is the intellectual device of human beings who impose themselves, and that the universality of language is ensured only by the inner form which each consciousness has in common before the perspectives (WM 443 4) or concrete contents, is pervasive. Here, we meet consciousness-centered, metaphysical way of thinking which

22) Relating to the debate between Gadamer and Derrida, see Dialogue and deconstruction: the Gadamer-Derrida encounter (Diane P. Michelfelder $\&$ Richard E. Palmer (ed.), State University of New York Press, Albany, 1989). 
supposes form independent of content, and once again privileges the rationality of human beings. Here, the universality of language is merely from human beings.

Of course, we can never deny that the fact that only human beings have language is often related to a human feature, self-imposition. Human beings have specific distance from beings, which enables human beings to impose themselves (WM 449). It is obvious that language ensures that a human being has its own 'world' in which it resides.

However, the very fact that beings are not given 'in themselves,' but are disclosed from the start in the understanding of being which is 'mine,' and that language does not differ from the distancing articulation of my finite understanding, suggests at the same time that my 'understanding' of my 'being' is the unnoticed ground for language and interpretation. Dasein brings beings in my disclosure into words. The language that is correlated with the world is the name for the occurrence that beings enter into the disclosure which is mine. Therefore, we can say that language is not a mere work of consciousness, but the articulation of 'understanding' which is the ground of them and given from Being itself. The truth that beings can be disclosed in my understanding and brought into words requires that we think of language in a different way.

Because Derrida walked the anti-metaphysical way of thinking, he could not admit the 'universality' of language, which could ground another 'identity' or oneness. It is beyond dispute that Derrida doubted the universality of hermeneutic experience or conversation, because his ontology does not allow it. In Derrida, there is no unifying connection between archi-text and language, because the former is absolutely other than the latter, not to mention the interpretation of 
language. He aimed to explicate the otherness that can never be mediated by Hegelian dialectics, which unifies all the differences by the movement of absolute spirit.

However, he also fails to locate properly the 'origin' of mineness of my being at each moment, or notice the unparalleled relationship between consciousness, the understanding and their origin. He cannot see the difference 'and' identity of the origin and our being at the same time. Although the finite interpretations are in some respect 'different' from the infinite movement of the text, since formers are able to formulate latter anew, we can also say that the interpretation is that of the text itself, that they should also be in some respect 'identical,' capable of being 'fused.' Derrida should have thought the vertical 'hierarchy' in different way.

Language has the universality from Being itself which occurs through our finite being. Language, as the occurrence of beings, is the middle (Mitte) through which what is to be said, or Being, meets our interpretation or understanding. Since Derrida refused to think Being itself, he could not think that the middle is from its nature that of "conversation (WM 450)."23) Derrida plausibly turns down the violence of oneness, yet goes too far in disregarding the unique dynamic of Being, its ceaseless engendering. Of course, we can find the infinite alteration of the meaning in Derrida. His

23) There is no room here for the discussion of the difference between Heidegger and Gadamer. To briefly comment, there is an opinion that they are different in the understanding of 'intersubjectivity.' However, Heidegger's ontology can never be that of an isolated subject even though it seems that he focuses on "subjectivity," not intersubjectivity. His ontology is already that of a Dasein who is in its finitude and thus necessarily in the constant relation to the Other or others. Therefore, it is crucial for the well-guided understanding of the relationship between Heidegger and Gadamer, to know finitude of our being. 
language also is in ceaseless movement.

However, what performs the substitution here is not archi-trace itself but just 'consciousness,' which is cut off from archi-trace 'after' the very occurrence. Derrida believes that he joints the form with force in his way, but the force in his thought cannot engender beings in new understanding again and again, but rather degenerates to the force of repeating the reflection of that which was once engendered, in the very opposite way of that of metaphysics which supposes the eternal 'presence' of the origin. Therefore, it is not surprising that he calls archi-text the 'dead,' absolute 'past,' against living determination. Only when we stop the movement of Being in our consciousness and reflect it, can it be the dead trace which has lost its vital dynamic.

In this way, a new meaning of a once-happened occurrence replaces the old one, and this process never concluded. I dare say that in this situation, the Other is actually no more than the origin of the other 'possibilities' of a possibility which is already actualized by my accomplishment. These other 'possibilities' are residues of what happened. When we stop to think what the other 'possibilities' were, we come to be conscious of the infinite 'possibilities' which were abandoned through the actual accomplishment of my possibility at some moment. In that respect, my actual accomplishment of understanding, and thus the disclosed beings in it, can never exhaust the origin of them. The origin includes all the 'possibilities' by its structural indecidability.

However, these 'possibilities' can be regarded 'infinite (eternal)'24)

24) We find here a shift of the meaning of "infinity" again. In Derrida, infinity means eternity, which is, however, anti-metaphysical, thus what is never realized but deferred forever. I would like to call Derrida a 'purist,' who cannot accept that the infinite gives itself only 
only by the specific understanding, that is, self-reflecting consciousness which is inauthentic, that is, refuses to be assimilated into accomplishment insisting on its autonomy. The way our actual understanding relates to the abandoned 'possibilities' is entirely different from that. When I accomplish my possibility, I do not count all the 'possibilities' in front of me one by one, which is impossible and useless. In the authentic way of being, with the help of consciousness, I actually accomplish a possibility at each moment by continuing to exist, and in this way, I already take a certain attitude about the other 'possibilities.'

When I think that I am already on the way from myself and to myself (Sich-vorweg), and that I am always urged to be on the way (Bewegtheit), this does not mean that the inexhaustible richness is merely the ceaseless mutation of structural 'possibilities' with de facto monotony, interminability or infinite iteration. Infinity cannot be reduced to the structurally infinite possibilities of 'substitutions.' Rather, the movement which never ceases to engender beings through my disclosure enables the singularities which can never be substituted.

Because he could not clarify the origin of consciousness that enables its twofold characteristic in the dynamic movement of occurrence, Derrida should have bit the bullet and paid the consequences by announcing our 'tragic' situation. We are allowed only to try to stay in the "margin" of philosophy at best. He surely paid attention to the tragic situation which we confront, and warned of the

into finitude, and thus is always 'imperfect.' In the eternal deferral which still engenders an abyss between the infinite and us, he wanted to save the 'perfection' unimpaired by our actual finitude. He dreams of the 'authenticity' which is 'separated' from 'inauthenticity,' of course not in Heidegerrian way, because he cannot see the genuine relationship between our consciousness and being. 
over-confidence of consciousness. However, from the absolute Other, we can get no ground on which we have a conversation with others, even though his main concern was recognition of diversity and the tolerance of difference. ${ }^{25)}$

I have to say that this position is intimately related to his belief that Heideggerian 'Being itself' is a metaphysical device which re-invites the myth of unity or oneness, that is, appeals to the eternal presence of being. Now we find the Being that is the origin of beings and 'different' from them, and that is not an eternal presence but an eternal 'deferral.' However, we also want the Being that is not merely different from our being, and that is always now and here not merely in hope and despair.

\section{Occurrence and Annihilation}

In seeking the reconciliation between what is finite and what is infinite, we are faced with a double task. We should neither eliminate the openness of Being and confine it into unifying totality by making our consciousness the all-embracing reason, nor suppose Being as the absolutely different Other which slips away from us by making our consciousness helpless. We are between the devil and deep blue sea of drastic optimism and pessimism which are up to the power of consciousness. In other words, we are required not to miss the dynamic of Being which is 'open through' our disclosure, and thus to think the genuine co-belongingness of Being with our Thinking. We are required to elucidate the metaphysical way of thinking of 'consciousness' which aims at timeless or non-temporal beingness

25) In this ontological presupposition, even the minimum requirement of morality that we should admit difference is impossible, which is a relevant criticism of Levinas, too. 
(Seiendheit), in the relationship itself between Thinking and Being.

Let us start with the Derridian thought again. In him, the origin remains as the Other which is other than beings, or, more precisely, the understanding which discloses them in a multiple singularity. Then, an appearance, a lightened feature, cannot but degenerate into a 'ghost,' a mere pseudo-image, because above all, it cannot rely on 'beingness' as the end of it, and secondly, it therefore cannot escape the fact that it is finite compared to the structural infinity which is other than the finites, and, thus 'partial' again. In this way of thinking, we cannot but denounce the finites. To stop its degeneration into image, to save what is finite, we cannot be content with the negative criticism of the violence of the metaphysical project as Derrida proposes. We should be able to rehabilitate the appearance in a positive way against the determination of consciousness. And to do this, above all, we should rethink the 'difference' between the finites and the infinites. The finite disclosure and the 'image' are possible only from Being. They do not originate from mere human invention. Dasein itself as the place of disclosure is a mortal being which has its own perspective at each moment. Seen from consciousness which seeks for its perfect control over beings, it means that the totality and eternality, that is, infinity, is not of Dasein, however, from the other point of view, it is a present (Geschenk) which enables me to be 'myself.' I am myself because of my perspective and mortality, and only these allow me to undergo all my pleasures and sufferings as mine. Both the thrill of butterflies at the beginning of a new relationship, and the sincerity of the whole heart in an old relationship, are possible only when I am in my concrete singularity.

Even for those who do not agree that life is a 'present' at all, 
who feel that the life is a heavy burden, it is impossible to erase their singularity entirely, or to avert from it, as long as they exist. Therefore, even though being is not a pleasurable present, it is still a gift. However, if it can be unpleasant, why is my being a present? For me my finite being is a present, because it is characterized by the invading approach even against our will. Even though I pray that I would never wake up next morning, my being continues. Being pushes and threatens me, apart from my arbitrary will, that in my disclosure something appears and disappears just as it. After all, I and my disclosure, thus all beings in this disclosure, are given from Being itself which is coming up or approaching to the here and now.

Our consciousness does not think of the origin of pre-sence (An-wesen) 26) of the finites, and tries only to pin it down into a still point of time, a 'now (Jetzt).' Even when it considers past or future, it still does not think the dynamic which moves the flow of time. Gathering points can not let time flow. In this way of thinking, presence (Gegenwart) becomes a glass cabinet which contains various dead insects which wait for a safe investigation. Here, our consciousness is surely no more than a faculty which grasps the 'spatial' differences by the division and comparison of the finites with each other, and of course eliminates the singularities only to discover universalities even in the form of the non-temporal or timeless 'essences.' Since philosophy has been led by this

26) Here, it does not mean the mere presence of beings (Vorhandenheit) as the result of appearance which is grasped by consciousness. Here, it is thought from Being itself, and is used to elucidate the coming-on of Being into the finites. Relating to the concept "An-wesen," see Hermann Mörchen, "Heidegger Satz: » >Sein< heißt >An-wesen<«" (in Forum fúr Philosophie Bad Homburg(Hrsg.), Martin Heidegger: Innen-und Außenansichten, Suhrkamp, Frankfurt a. M., 1989). 
consciousness, or, since philosophy has encouraged the arbitrariness of consciousness in this way, it has paid more attention to the spatial characteristic than to the temporal characteristic of being.

However, spatial and temporal characteristics are never separable. Even the process of consciousness needs the inner time for its survey. If consciousness cannot web the knots of its being anew and anew, it can never accumulate its knowledge at all. Therefore, even consciousness is not released from thinking of time, and philosophy cannot but question time according to its own light, even if in the manner of crystallization of time into infinity as completeness. ${ }^{27)}$

Thinking of Being properly means thinking of it as 'Coming-on (Zu-kunft).' Presence is only possible from the coming of Being into space of the here and now. Through my "de-termination (Entschlossenheit)," which bursts a limit just before and creates a new singularity, the appearing being can be itself (SZ 431). My being at each moment is not just staying 'in' its inside. The limit at each moment is, as long as it contains singularity, determined, but this determination is at the same time de-termination, which makes me already open at each moment, without which I can never continue to be. ${ }^{28)}$ Dasein is as the-being-already-forward-of-itself-in-the -world-with- other-beings (Sichvorweg-schon-sein-in-einer-Welt-als-Sein-bei-innerweltilch-begegnendem-

27) On the contrary, without the spatial characteristic, that is, the difference between beings, the temporal characteristic, that is, the passing change, cannot happen, either. What has no determination can never undergo change. The totality is imagined not to move at all, at least in the whole. Therefore, in Heidegger, who asks above all about the temporality of being against the metaphysical way of thinking, another characteristic of being still matters. His thought is also about 'my' being, 'my' world, and the netting (Geflecht) and gathering (Sammlung) of Being.

28) Therefore, death is always there, but nowhere as long as I exist. 
Seienden, SZ 432).29) Then, in the 'being-already-forward-of-itself' my being is 'arriving' on me. At each present moment I am myself with everything I understand, however, at the same time, more than it.

Here, in this 'transcendence, ${ }^{30)}$ announces Being itself. However, we should note that it is as comingcoming-on only through Dasein. Being is not a 'transcendental' being 'beyond' us. There is no Being as a being outside us. Being announces itself as approaching human beings (BF 14) whose being is only in finitude. Through finite being of Dasein, Being itself comes finite (SZ 436). The finitude of our being is no more than the dynamic of Being itself which is finite. The time times and the space spaces, which is the breaking of the path open or the way-making for itself by Being itself.

Therefore, we cannot say that only Being itself is infinite, and thus other than our Thinking31) which is finite. Rather, in the manner that Thinking is a way which Being itself makes, Thinking and Being co-belong to each other. A notorious saying of Parmenides, "Thinking and Being are the same (to gar auto noein estin te kai einai, Parmenides fragment 3)." describes this kind of dynamic of Being coming into finitude through Thinking. The tradition could not see the genuine co-belongingness of Being and Thinking, because it

29) Here, we reaffirm the relationship between present, future and past, or that between space and time. Since future comes as present only through a world which is already mine and which thus has its own texture, we can say that future comes also from past, in continuum.

30) I reject to use this word in traditional way, which is the main theme of this paper. 'Transcendence' means the movement of being to go beyond some limits or boundaries. However, it is not a mere quality of a being (beingness like God), but the dynamic Being itself. Being itself is transcendence, which never means that Being transcends this mundane world. It must be understood above all in the perspective of 'time.'

31) Thinking as understanding Being. 
could not see Being as coming-on dynamically into finitude. Only in this way, the appearances of beings are not mere 'images.' It is the faces of Being itself, which cannot disguise the 'truth.'

However, the truth does not come as mere truth. It is untruth at the same time. Because of the co-belongingness of Thinking and Being, Being comes not only as pre-sence (An-wesen) but also as ab-sence (Ab-wesen). Thinking pre-sents Being and ab-sents it, because at each moment, Thinking de-termines its determination at the same time. That Being gives itself through finitude, means that Being gives itself as what are different from each other and what are changing at each moment. Everything in my disclosure gets articulated in space and time. Here, we definitely see the 'void' which makes no mere 'break,' but gives my world an alive multiple singularity in my ending. Void 'occurs' in a double way. The void is the border on which each of the singularities loses its ground, thus the "rift (Riß)" between me and you, present me and coming and approaching me, is never fastened.

(a) Among all of beings at a moment, there must be a rift. I do not mean here the mere optical line which seems to divide the individuals. My being is not confined in my optical outline at all. However, as long as my world is mine, it must have a difference with yours, in order to have its own clearing. Further, because my world consists of the relationships among inner-worldly beings, the beings must have a rift among them which is different from yours. (b) My disclosure itself suffers changes ceaselessly. My disclosure of one moment has a rift between it and that of another moment. Without it, the disclosures of two moments cannot be different at all, and cannot undergo any change. Therefore, beings must have a rift between them everywhere, which always differs. 
Void is neither merely nothing, nor something, but is 'in' the occurrence of Being as such. It is contained only in Being (BF 18) which is in a finite dynamic. Being differs itself into beings, and the rift itself is the path to beings, which is drawn by Being. The occurrence of Being gives itself by tearing itself into pieces, thus tearing open the way (Be-wëgen) (US 186). Therefore, it could be thought that when Being is in its occurrence, it also is as the annihilation (Vernichtung) of itself. And Being is itself the profound conflict (Urstreit) in which the open middle (Mitte) of finite beings is won ( $\mathrm{H} \mathrm{42).} \mathrm{In} \mathrm{the} \mathrm{Thinking} \mathrm{which} \mathrm{Being} \mathrm{is} \mathrm{concerned} \mathrm{(angehen),}$ Being withdraws and conceals itself. A disclosure (Lichtung) into which beings come to stand, is itself at the same time a closure (Verbergung) ( $\mathrm{H} 40)$. We recollect that a long time ago Heraclitus said that "Being likes to conceal itself (physis de kryptesthai philei, Heraclitus fragment 123)."

In this way, occurrence is un-concealment (a-letheia), and truth (a-letheia) is untruth. To escape the persistent dichotomy of truth and image, Heidegger suggests a new concept of 'truth (Wahrheit)' as the occurrence of disclosure, on which even the metaphysical concept of truth as the correctness (Richtigkeit), the correspondence between consciousness and the so-called 'fact (not actual being, but hardened entities or beingness)' is grounded. Untruth (Unwahrheit) is already in this truth, that is, truth occurs only as untruth, and beings are finite. Since here untruth is not a mere fault, but a necessary texture of truth itself, even if not in a 'logical' sense, there is no justifiable reason to belittle the untruth which fills the finitude.

To emphasize again, when we say that Being conceals itself and truth is untruth, it does not mean that there is something else which 
is concealed from our disclosure. However, when Heidegger says that Being withdraws itself from our Thinking, this cannot mean that Being step backward from human understanding, that is, to the space of spurious infinity. If so, Being would again become a kind of substantial thing which has the characteristic of nothingness against us. However, in Heidegger, Being definitely gives itself to us, if only through our finitude.

However, if that is the case, I should justify the expressions that arouse misunderstanding. I said that Being conceals itself. Here, Being is the 'subject' of a sentence. However, Being is not a subject that wills. Those who write, draw and compose, listen to the voice of what is to be written, drawn and composed by them, before it has its existence through them. What is to be said says itself. When I write a paper, however clear my intention and the plans in my consciousness might seem, the composition of chapters, the structures of sentences and the choice of individual words can never be confirmed before my actual writing. And in the process of my writing and determination of them, I slowly come to know what I am trying to write down. And only at the end of my writing, I can say that I actually know what is said. What is said is not outside of me as what 'should' be said nor what 'wills' to be said. Therefore, it is no substance, no subject, even though we cannot but put it in the place of a subject of sentence. When we say that spring comes, we never think spring as a substance which has its will to push away the chilly winter and come here. However, we should admit that there are cases that demand Being itself as the subject of sentences, if it is to be said at all. There are cases that we can think only by letting 'Being itself' be a subject of a sentence.

This case which demands Being as a subject of a sentence, is 
related to what is 'infinite.' That which gives itself through finitude, but at the same time 'annihilates' the finitude, and thus even 'conceals' itself in finitude is 'in'-finite. However, this cannot be the same as infinity, just as our finitude is not the same as finiteness. Therefore, I would like to call it 'infinitude,' which is finitude and its negation at the same time. Now, we see the reconciliation of what is finite and what is infinite, finitude and infinitude. And I also say that if finitude is characterized by singularity, then infinitude is characterized by openness to the annihilation of finitude. ${ }^{32)}$ Infinitude no longer let us exaggerate or minimize our own importance.

\section{Conversation}

We can finally deal with the issue of 'consciousness' in its actual state for the first time. I said that Being which itself offers the abyss is surely neither merely identical with, nor merely different from our Thinking. Rather, as it is seen above, Being is 'nearest' to us, but 'farthest' from us at the same time. In Heidegger, the nearness (Nähe) of Being is in itself distance (Ferne). Nearness and distance name the same. Only in the happening of nearness, the distance stays and is retained (BF 24).

Being is nearest to us in that we always understand Being. However, Being occurs only as annihilation, that is, it gives itself only through finitude, in singularity. Even though we have thought the rift already, we did not yet think enough about self-differentiation

32) And we can see that infinitude itself is the origin of totality and eternity, because infinitude gives itself into space and time. However, this new concept of infinitude means neither the elimination of the dynamic of Being itself, nor the denial of the case that finitude is accomplished by our own disclosure. 
into the finites, or the dynamic of Being. I want to ask what happens when the transfer or fusion between singularities occurs. In Heidegger, "language" is above all the path that Being breaks in its movement. Here, above all, we can say that a spoken word comes from Being as such which comes and gives itself in the finitude of my disclosure by self-annihilation. Where there is no language, there are no beings (US 182), not because language preexists beings, but because it is found only where Being gives itself, where Being is saying through my understanding. In language, Being is near to us.

However, this does not mean that language does not belong to human beings. The self-annihilating occurrence of Being requires a room in us the finites, too. If we have no 'freedom' at all which is given by Being, we are machines that exercise a pre-programmed progress from the starting point, or at most the results which are followed from causes in our environment, in a mechanical order. In that case, Being itself would come to a complete end again. Therefore, in language, which is the way of Being through our disclosure, the room is given to us, in which we have our limited ${ }^{33)}$ 'freedom.' The 'imagination' which opens new possibilities grows in this room and consciousness which has its own space has its power from this 'distance.' All of philosophy is familiar with this distance, as long as it admits the possibility of philosophy.

That human beings speak language means here that we are taking

33) Of course, I cannot go far away with the accomplishment of my possibility, because my possibility is mine, which means future is already of past. Once a tradition is chosen, it can never be erased. We cannot escape being pushed by tradition. However, even though I am not as 'free' from the finite as consciousness dreams, I am free from the infinite much more than consciousness supposes. Because infinitude has no end and it is necessarily open, the concrete direction can still be decided by us ourselves. 
beings in a specific 'attitude (US 177),' by which we can take part in the decision of our own possibility. In language, Annihilation of Being is also as the opening of the 'distance' from Being to Thinking. It is not a mere gap, but an opportunity for us, because this distance is the space in which our understanding performs play. In this 'distance,' we are confronted again with the fact that my being is open to myself as that for which I should take responsibility. Here, there is an opportunity for us to be a counterpart in 'conversation' with Being or, thereby, with others. Without this conversation Being can not be the 'farthest,' that is, we can not be forgetful of Being. We do not think Being but run away from Thinking it.

As matter of fact, we have taken part in this necessary conversation by refusing to think the responsibility of our own being, and thus failing to have a conversation with Being. Heidegger calls this situation the 'forgetfulness (Vergessenheit) (ID 59)' or 'leaving (Verlassenheit) (BP 66)' of Being which gives itself as finitude through myself. ${ }^{34)}$ When I remember Being, consciousness serves for understanding. This is, when Dasein exists authentically, consciousness as the self-reflection of this distance explores this space and helps my understanding choose a possibility by lightening the possibilities. The person who reflects can have 'more' possibilities for his or her being. This 'more' does not mean merely the number of empty possibilities, but the depth of possibility. When the reflection of my own value matters through and through, my actual accomplishment of possibility gets its depth, whether by suffering or by confidence.

34) Furthermore, as a finite being I must take responsibility for my past, not to mention my future. I am still taking responsibility for the past which is inherited from those with whom I had conversation, and who have chosen to forget Being. It could be said that we are given the inclination of forgetfulness of Being. 
However, for a very long time, human beings have chosen to forget Being, which is the origin of the finitude of our being, and thus to forget our responsibility to enter into conversation with Being. And here, Being 'conceals' itself from our consciousness, and retreats to a farness without nearness. Of course, we can never run away from Being completely and we are still speaking something, although we try not to remember its truth as untruth. Existing inauthentically, human beings stop thinking Being as such, and rely on consciousness which has lost its origin and believes that it can surpass its limitation. Consciousness conceives by its own power the unity beyond all the finite differences and always aims at reconciliation with it, because it comes to believe that it has wings that can reach anywhere. This is not, however, a genuine conversation with Being itself, but a monologue without hearing. We find the abyss between Thinking and Being hopeless.

However, since language is given as the way of Being which is the nearest 'and' the farthest, for us the 'conversation' with Being is possible and even required. I do not mean this word "require" in ethical meaning. This requirement precedes ethics, and enables it. My being is up to me as mine, therefore, I need a ethics. The conversation is the possibility of possibilities of my being. We can, and should hear (hören) the saying of Being, by responding to it and speaking along with it (nachsprechen) in our way.

Maybe we give up thinking Being and hold by the abstract and universal, that is, non-temporal and timeless knowledge, because it is so painful to think Being. Among human beings who are in their own singularity, there is always the matter of that causes conflict and suffering that can never be ultimately resolved.35) My voice

35) Because Being gives itself through finitude, the conversation with 
cannot reach his mind, her voice breaks the peace of my mind. But I have to bear this situation without escape. I always regret for what I have done, and still, I cannot choose my future with confidence. Restlessness and Anxiety is our closest friend. It is not bearable that the only thing which is allowed us is finitude, that we should stand in the singularity 'and' in the openness to the last breath without any promise. Therefore, we want to secure our continued existence, even in a more safe and comfortable way, by supposing an infinity which is eternal and total, that is, by the forgetfulness of Being. This kind of endeavor might be unavoidable for us.

Of course, we can choose to blame Being for our forgetfulness of Being. This is because Being itself, which occurs in annihilation, gives us an abyss for our 'freedom.' To be infinitude, Being itself needs the 'abyss.' However, we are endowed with the ability of being, the accomplishment of our own possibility, in the conversation with Being, from Being itself. This means that any way I am responsible for my being.

We can accomplish our possibility in a different depth, and we therefore have the opportunity to have a bad conversation by imposing ourselves without hearing. We have ears that are supposed to be open all the time, but can to some extent be plugged. I can not say

Being is also the conversation with others. In a conversation between two people, a 'complete' correspondence between their understandings is never acquired. Their languages cannot refer to a monosemic meaning, because each of them is finite in her own singularity. What happens in conversation is the encounter of two worlds and the fusion of them, not the entire assimilation which would mean the dissolution of at least one person. Conversation actually transforms my possibility and my being undergoes actual change in a conversation. Here, there can be no complete 'understanding' of the other. However, we can also say that there is no complete 'misunderstanding' in conversation, which is the concept that prioritizes one side's intention. 
that the 'deepest' being is the best. It never guarantees so called happy life, but it can deepen your joys and sorrows of life, because it makes you awake. I can not insist with right that you should accomplish the deepest being, or in Heidegger's words, the authentic being.

However, the situation in which we do not enjoy our finitude and everything is dumped into the 'nothing (nihil)' opposite to the completeness, is not forced on us, either.36) We are not 'destined' to do it. We can still bring our being into question. All the time I am already taking part in the conversation with Being, and thus with others. Since we are in finitude, we are always responsible for our own being. The fact that we do not want to do it, still means that we are pushed to take the responsibility for our own being. Therefore, we should beware of all the philosophies which say that we cannot ask, or we no longer need to ask. As long as I do not forget to exist finitely, this conversation will be alive.

We are not supposed to be content with stiffened standards. It is

36) In his middle phase when he pays attention to the self-withdrawal of Being and tries to establish thought in Being itself, even Heidegger himself thinks that the concealment of Being offers a mere 'image' or 'disguising,' (H 40) and that our Thinking should tear off (aufreißen) the concealment and establish (stiften) the unconcealed truth firmly. However, in his late phase, he comes to admit that his own endeavor still helped consciousness to impose itself without the remembrance of Being, and that the untruth is not merely an eradicable error or misleading (Irre). The person who wants fight against the acquirement of the power of consciousness becomes one who accepts the given in a more humble manner. In his late phase, Heidegger seems to resign our fate to Being itself. However, when the late Heidegger talks about the resignation to our 'fate,' this fate means finitude, not the mere forgetfulness of Being. When we admit the infinite coming-on of Being as finitude, when we let the coming-on be itself, we can be the finite being who converse with Being and take on the responsibility of that conversation. 
not conversation to mirror oneself in the dead eyes of those who do not listen to one's words. Conversation alerts us to the danger posed by the promise of infinity and completeness in its mundane version which consoles our fatigued existence. Even though we can never attain final unity or oneness in conversation, the process of conversation will make us alive in finitude. Just by taking part in the conversation, which is the weightiest responsibility and the most pleasurable gift, I am myself, alive and with dignity. 


\section{REFERENCES}

Alberto Rosales, "Heideggers Kehre im Lichte ihrer Interpretationen," in Dietrich Papenfuss u. Otto Poggeler (Hrsg.), Zur Philosophischen Aktualitat Heideggers, Bd. 4, Vittorio Klostermann, Frankfurt a.M., 1989.

Barbara Merker, "Konversion statt Reflexion-Eine Grundfigur der Philsophie Martin Heideggers", in Forum für Philosophie Bad Homburg (Hrsg.), Martin Heidegger: Innen-und Außenansichten, Suhrkamp, Frankfurt a.M., 1989.

Diane P. Michelfelder \& Richard E. Palmer (ed.), Dialogue and deconstruction: the Gadamer-Derida encounter, State University of New York Press, Albany, 1989.

Georg Wilhelm Friedrich Hegel, Wissenschaft der Logic, Hegel Werke Bd. 5, Suhrkamp, Frankfurt a.M., 1979. (Ab. WL)

Hermann Mörchen, "Heidegger Satz: » >Sein $<$ heißt $>$ An-wesen<«", in Forum für Philosophie Bad Homburg (Hrsg.), Martin Heidegger: Innen-und Außenansichten, Suhrkamp, Frankfurt a. M., 1989.

Hans Georg Gadamer, Wahrheit und Methode, Gesammelte Werke Bd. 1, Mohr, Tübingen, 1986. (Ab. WM)

Jae Chul Youm, Heideggers Verwandlung des Denkens, Königshausen \&Neumann, Würzburg, 1995.

Jacques Derrida, Margins of Philosophy, Alan Bass (tr.), Hervester Press, Brighton, 1982. (Ab. MP) , Writing and Difference, Alan Bass (tr.), the University of Chicago Press, Chicago, 1978. (Ab. WD) 
, Negotiations: Interventions and interviews, 1971-2001,

Elizabeth N. Rottenberg (ed.), Stanford University Press, Stanford, 2002. (Ab. NII)

Karin de Boer, Thinking in the Light of Time, Heidegger's encounter with Hegel, State University of New York Press, Albany, 2000.

Karl Heinz Volkmann Schluck, Einführung in das philosophische Denken, Klostermann, Frankfurt a.M., 1975.

Martin Heidegger, Beiträge zur Philosophie, Vittorio Klostermann, Frankfurt a.M., 1989. (Ab. BP)

, Bremer und Freiburger Vorträge, Vittorio Klostermann, Frankfurt a.M., 1994. (Ab. BF)

, Einführung in die Metaphysik, Vittorio Klostermann, Frankfurt a.M., 1976. (Ab. EM)

, Holzwege, Vittorio Klostermann, Frankfurt a.M., 1977. (Ab. H)

, Identität und Differenz, Vittorio Klostermann, Frankfurt a.M., 2006. (Ab. ID)

, Ontologie: Hermeneutik der Faktizität, Vittorio

Klostermann, Frankfurt a.M., 1988. (Ab. O)

, Sein und Zeit, Vittorio Klostermann, Frankfurt a.M., 1976. (Ab. SZ)

, Wegmarken, Vittorio Klostermann, Frankfurt a.M., 1976. (Ab. W)

, Unterwegs zur Sprache, Vittorio Klostermann, Frankfurt a.M., 1985. (Ab. US)

Rodolphe Gasché, Inventions of Difference, on Jacques Derrida, Harvard University Press, Cambridge, Massachusetts, London, England, 1994. (Ab. IDJ)

, The Tain of the Mirror, Derrida and the Philosophy 
of Reflection, Harvard University Press, Cambridge, Massachusetts, London, England, 1986.

Walter Schultz, "Über den philosophiegeschichtlichen Ort Martin Heideggers," in Otto Pöggeler (Hrsg.), Heidegger: -Perspektiven zur Deutung seines Werkes, Kiepenhauer\&Witsch, Köln, Berlin, 1970. 
국문요약

\section{유한성을 통한 존재 사유}

\section{박 현 정}

' 1 장: 의식과 무한성'에서는 전통 형이상학이 무한성(infinity)과 유한성 (finiteness)을 다루는 방식을 간략히 밝히게 된다. 전통 형이상학은 의식의 자기 대상화를 통해 스스로의 '불완전성'을 인식한다. 그리고 이를 부정하고 극복하기 위해 모든 유한자들 너머에, 절대적 의식인 이성이 포착할 수 있 는 ‘무한성'을 상정하고 이를 목적으로 삼게 된다. 이때의 무한성이란 영원 성과 결합한 총체성을 의미한다. 이러한 유한성의 반대항으로서의 무한성의 상정과 함께, 인간의 구체적 실존은 그 개별성으로 인해 다시금 '유한한' 것 으로 폄하된다. 그리고 이로써 우리는 서로 대립되는 것의 결합을 요구하는, 실은 해소할 수 없는 이분법으로 인해 고통받게 된다. '2장: 헤겔과 형이상 학의 마지막 해법'에서는 유한성과 무한성을 성공적으로 결합한 것으로 평 가되는 헤겔의 성찰적 논리학을 간략히 살펴본다. 그는 전통 형이상학의 악 무한속에서 발견되는 의식의 무력함을 부정했고, 우리와 절대적 존재 사이 에 존재하는 변경을 제거하였다. 그에게서 존재는 총체성에 이르기까지 끊 임없이 운동하는 것이고, 이 운동은 철저히 유한한 의식을 통해 이루어진다. 이 장에서는 전통 형이상학이 시도해 온 무한성과 유한성의 결합의 최종적 인 결실로서의 헤겔의 사유는, 실은 존재를 총체적 체계 안으로 포섭하는 질서를 상정해낼 수 있는 스스로의 힘을 의식이 자각함으로써 가능했던 것 임을 밝히고자 한다. '3장: 하이데거 그리고 존재와 사유의 공속성'에서는 전통적 형이상학은 사유하지 못했던 것, 즉 의식이 뜻대로 할 수 없는 존재 자체, 그리고 이 존재와 사유의 진정한 '공속성'을 다루게 된다. 이 공속성 으로부터 우리의 존재는 열려있는 것이 되고 우리는 우리 자신의 존재를 수 행할 책임을 떠맡게 된다. 여기에서, 사유와 하나인, 따라서 언제나 새로운 의미에서 언제나 ‘유한성(finitude)' 속에 있는 존재 자체의 요구로부터 전통 적인 유한성과 무한성의 개념은 포기되어야 하는 것임을 드러날 것이다. '4 
장: 무화하는 일어남을 둘러싼 데리다와 하이데거의 대결'에서는 존재 자체 에 대한 좀 더 깊은 해명이 이루어질 것이다. 존재와 사유의 공속성이 우리 에게 수행하도록 요구하는 우리의 이해에 있어, 존재 자체가 유한성을 가능 케 한다는 것이 어떤 의미일 수 있는지를 밝히기 위해서는 존재 자체의 '일 어남', 좀 더 정확히는 동시적인 ‘무화’를 새로이 사유하는 것이 무엇보다 중요함을 보이게 된다. 여기서는 하이데거 사유에서 존재의 자기 빼냄, 혹은 무화의 참뜻을 살펴봄으로써 현재 혹은 현전하는 것의 타자성에 대한 사유 인 소위 포스트모더니즘 철학이 아직 미처 다 길어내지 못한 하이데거 사유 의 가능성을 밝혀내고자 한다. 본 논문에서는 특히 헤겔적 '동일성'을 사유 한 헤겔에 맞서, 기원의 '타자성' 또는 '차이'에 기반한 구조적 무한성인 '차 연'을 탐구한 데리다에 주목한다. 데리다의 이 개념은 존재의 무화로부터 요구된 것이었지만, 데리다 자신은 그것을 존재 자체를 망각한 의식에 의해 포착된 '현재'의 단순한 대체물로 삼는 데 그치고 말았다. 무화하는 일어남 을 다루는 이 장에서는 특히 언어의 문제를 다루게 될 것이다. 왜냐하면 데 리다와 후기 하이데거에게서 언어의 문제가 중요한 몫을 차지할 뿐 아니라, 실로 언어에서야말로 존재와 사유의 관계, 그리고 이들의 공속에 의한 유한 성의 문제가 가장 첨예하게 드러나기 때문이다. 본 논문은 3 장과 4장에서 한편으로는 헤겔과 초기 하이데거의 사유간의 차이를 밝혀내고자 하며, 다 른 한편 하이데거가 어째서 ‘존재 자체’를 끌어들일 수밖에 없었는지를 해 명함으로써 후기 하이데거 사유가 갖는 반-형이상학적 성격을 분명히 하고 자 한다. 궁극적으로, 본 논문은 존재와 인간 사유(그리고 의식)의 관계를 전통적 무한성과 유한성의 이분법의 극복인 새로운 유한성(finitude)의 개념 을 통해 드러냄으로써, 인간의 참된 현사실을 이해하고 그것을 있는 그대로 긍정할 필요를 말하고자 한다.

주제어 : 무한성, 유한성, 의식, 존재, 하이데거, 헤겔, 데리다 